\title{
9. How skilful communication won the real story A Timor-Leste theatre of intimidation, retrospective and 'Anti-News'
}

\begin{abstract}
This is an extract from a keynote address by film maker and journalist Max Stahl, director of the Centro Audiovisual Max Stahl Timor-Leste (CAMSTL), at the 20th anniversary conference of Pacific Journalism Review in November 2014. Stahl screened the first part of an 'experimental' film, The Reconciliation - a kind of 'anti-news' - and spoke about his methodology and stylistic approach in achieving something mainstream news, almost by definition, cannot. It tells the deeper story, or the many possible stories according to those actually involved inside the story, of a week in Timor Leste in 1999 prior to its independence from Indonesia. It is challenging. There are no resumés available. It is outside the privileged world of news.
\end{abstract}

Keywords: conflict reporting, current affairs, documentary, independence, political journalism, self-determination, story-telling, Timor Leste

M

AX STAHL is an independent film maker and photojournalist who has covered conflict from Africa to Asia. His work was recognised by UNESCO in 2012 as

a World Heritage. The images he filmed of the Dili massacre in 1991, which documented Indonesian soldiers shooting more than 250 unarmed students, was to institute political change in that nation. This change culminated in 1999, when the Timorese voted overwhelming for independence from their Indonesian occupiers, a stance which was, again, to provoke brutality and violence. Stahl was there again. His work is recognised internationally as pivotal, not only in documenting the trauma and the heroism of Timor-Leste's search for liberation but in engendering political change.

Timor-Leste is perhaps the first nation in history to have achieved its independence through the power of audiovisual images reaching out to the international community. These images of bravery and peaceful commitment inspired people around the world to share in an international intervention to foster a new nation. This was a struggle won by ideas and the story of how a tiny, almost forgotten, nation vastly weaker than its occupier came to inspirit and then involve the world in winning its freedom, breaking new ground in the fields of human rights and international order.

Max Stahl now lives in Timor-Leste with his family, and is the international director of CAMSTL (Max Stahl Active Archive and Cultural Resource Centre) which works to 


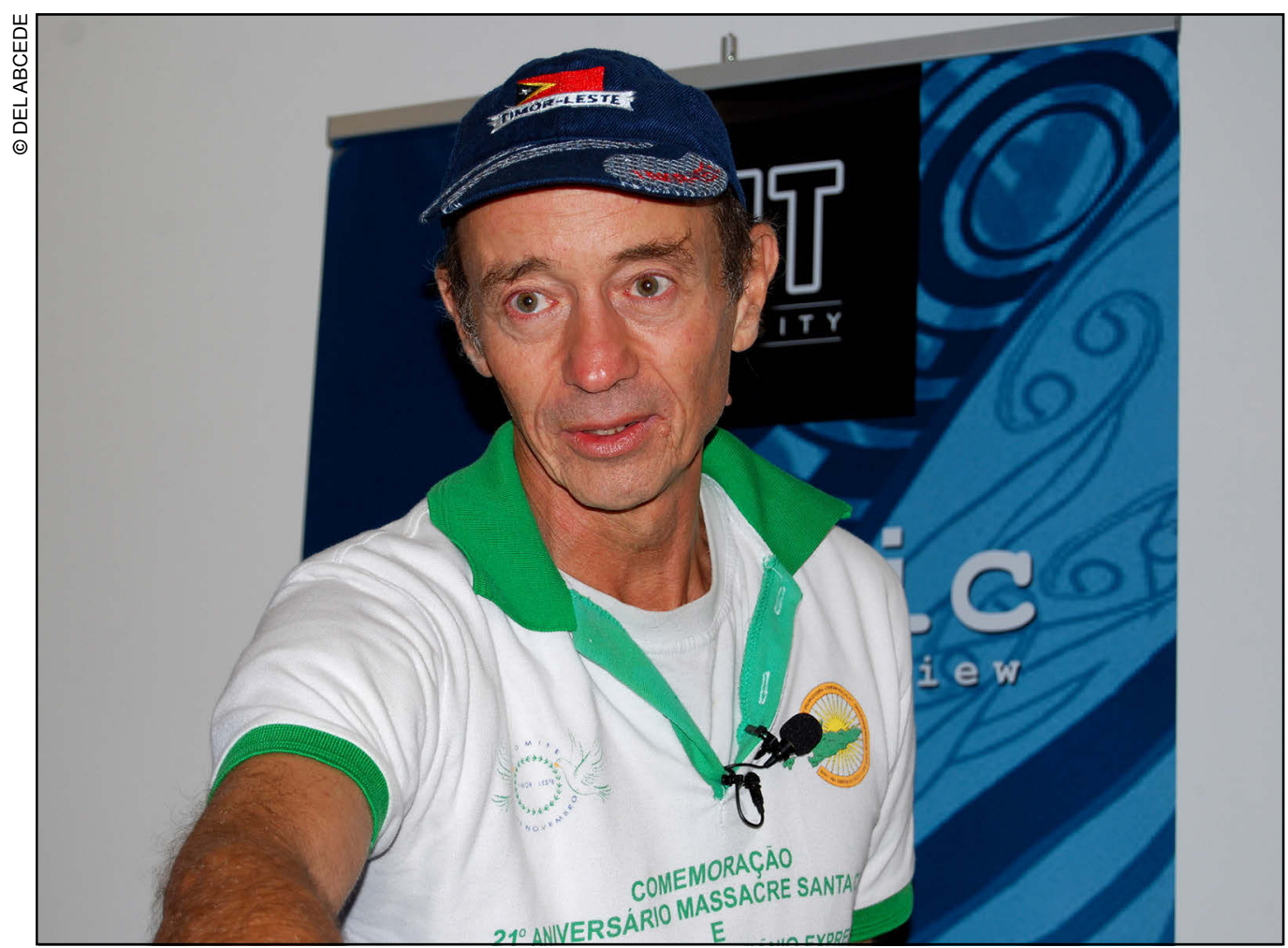

Figure 1: Max Stahl speaking at the Pacific Journalism Review 20th anniversary conference in Auckland in November 2014.

assist the newly independent nation in rediscovering its past and heritage; to unite and secure the identity of the country and its people; to contribute to the forging of a new democratic nation; and to explore and celebrate the living culture of Timor-Leste as an integral part of its life and development.

CAMSTL: tekeemedia.com/camstl/

\section{The Reconciliation and 'anti-news'}

Max Stahl: When you make a film you have to choose a scenario within which a work will take shape. Usually, you conduct research which then allows you to tell audiences what happened following a pre-conceived scenario. But that often doesn't actually explain what happened for the people who were part of the scene being filmed - the film is not a faithful record of what happened. That's one reason why people from inside a situation are often silent, bemused even, by later accounts of what occurred. It is not that they are inaccurate, but such accounts rarely conform to the subjects' experience... And this is a tricky issue, but our approach to the film is an attempt - just an attempt - to bridge this 
gap. "Newsmen the world over seek and celebrate "The Story". Hour by hour The Story may change, but always The News demands clarity and coherence. This is thought by editors to be an overriding virtue, even a precondition of 'The Truth', and necessary to merit the attention of the public. But this coherence fosters a big lie. For those involved in conflict, those whose choices we are trying to understand, such coherence is often artificial nonsense.

The Film: The Reconciliation Part 1 is the first of a four-part experimental projectfour hour films, made by selection of long takes with minimal editing, no extraneous sound and no verbal commentary. Its core premise is to stay faithful to the moment, to the uncertainty which is the essence of the experience of conflict, and to the multiple implicit outcomes which those inside a conflict must as a matter of urgency understand and react to, moment by moment. There is no extraneous or priveliged information, no explanation. This approach I call 'Anti-News' because it documents the people at the centre of multiple co-existing stories, matters of life and death, competing without any definitive thread or conclusion. When, in the end in late September 1999, suddenly the international forces arrive in Timor-Leste - an outcome defined at the last minute by decisions a world away — one of these versions is reflexively posited to be The Story of what happened, and this narrative marginalises and soon excludes the others.

Traces of uncertainty remain of course, even in the 'official' memory of the conflict in Timor-Leste. Today, Timor annually celebrates its original declaration of independence on 28 November 1975, the Restoration of Independence on 20 May 2002 when the UN formally handed over power to a Timorese administration, the referendum on 30 August 1999 when the nation voted overwhelmingly for independence despite systematic intimidation, and 4 September 1999 when the people's desire for independence was recognised internationaly and the result was anounced, despite mounting violence orchestrated by Indonesia. Each of these dates have their constituency and their story. For me and many others the key moment which gave birth to independence was none of these dates.

This approach I call 'Anti-News', which shows everybody's version of events of 1999 competing without any clear thread or conclusion, except in the end suddenly the Indonesian forces actually arrive. For me that was the key day, the moment when independence seemed likely.

In the CAMSTL audiovisual archive, we document many different aspects of the birth of the nation Timor-Leste through many stories: we have 4000 hours of material at present. We don't know entirely what the story will be; we don't do what one would normally do. We try to understand what the themes of significance are - they are not necessarily all political; they could be cultural, they could be sporting, all sorts; any themes that seem to have important aspects of the on-going story of Timor-Leste embedded in them.

When you get an opportunity, when there is a moment, when there is an audience, then you make a film from this archive of a history. You make it for the local people when there is an anniversary or when an issue arises. Or for foreigners who may come. 
The process of trying to document the birth of a nation is the ongoing task we have set ourselves in the archive. We draw on materials we have, but also go forward from these, looking to see what the key issues are, what is developing. There can be surprises, but you try to understand or try to keep material that is relevant and important. You may end up with a news story, or an adaptation of a local occasion-it becomes an edit for this, or a selection for that.

Very local people don't really want you to have selected material throughout your edit. To be quite frank, they want to look at as much of the old unedited material as possible. We always try to involve others in making films that are relevant to them. Local people work at the centre and often they go to the mountains and the communities, showing them material and capturing more that then allows us to further develop these stories. It's a constant process and outsiders also are engaged in this. We work with many filmmakers from all over the world: New Zealand, Canada, United States, Europe, France, England, and Portugal and most often, we are creatively involved. We ourselves also look back: this is part of a process which involves the founding memory of Timor-Leste.

It's a sad irony that the very countries that most need a story, a real story not an invented story, a founding story, are the very countries that don't have one, they don't have access to one. They' re split and fragmented by different founding stories or different versions, even of one. This is not a trivial matter as was made graphically evident to me during the crisis which exploded in Timor-Leste in 2006. Dili was in flames, there were 150,000 refugees again in a matter of days and it was a conflict it seemed over nothing: over a lack of respect allegedly shown by some officers (from the East) to others in the army (mainly from the West of the country). I remember filming some young men with iron bars and Molotov cocktails who were launching a burning car into the government palace where I worked. I asked one of them — just 17 years old — why? His answer-in the midst of smashing in windows - was instructive: it was a history lesson. The Indonesians, he said, did not invade Timor-Leste through the East, (which does not border on Indonesia), they came through the West.

The issue was one of pride, or dignity, defined by memory. By a founding story. Suffering is divisive. It fragments, humiliates and stultifies communities. But their shared experience can also be defining. Told in a founding story, it can be a powerful means of resurrection. But this is a perilous process dealing with raw sensibilities, explosive truths and half-truths. In 2006 Timor-Leste was thown back into the maelstrom because there was not enough trust shared in a common story.

It was a disaster-hundreds of thousands of people fled and the tensions lasted for years. During this process, some of the key leaders in Timor-Leste's epic struggle were very aware that we at CAMSTL had an important part to play. Our building was taken over by the head of the army police operation, which was sent to look for the militia in the hills.

The commander said to me, 'Look, I want you to go and show films to the people in

128 PACIFIC JOURNALISM REVIEW 21(1) 2015 
these communities, particularly the communities that were involved in this crisis' because they share a story, and that shared story is a foundation of stability, the foundation of an identity. And without an identity you don't have a democracy, you don't have a shared community, you don't have a nation. So, we are a part of that process. We are aware that there is a dimension you could call myth-making. But we do not invent myths. We certainly don't believe in inventions, in falsehoods. We are as rigorous as we can possibly be within our resources, more rigorous than journalists can generally afford to be, because we have more time and much more information. But every powerful story has its mythical dimension; indeed, most fiction films need a mythical dimension that enhances the details of a story before they get funded or succeed. We are active in working with different communities - I'm working with the Brazilians right now, for example — or Australia, New Zealand etc., but our stories have reached a scale where Hollywood is now involved. I just came from Timor and I was approached there by a producer who has raised financing to make a fiction film based upon a documentary, Alias Ruby Blade, which we made with some American filmmakers. The documentary traced the story of Kirsty Sword, the Australian political activist who married Xanana Gusmao — she was with us in the first film that I made in Timor while the country was still under Indonesia occupation. ${ }^{1}$

Audience speaker: There's one thing that I think you've left out of this narrative, Max, and that is your own role. I recall that terrible time just after the referendum in 1999 when Dili was in flames, and APEC was happening in Auckland. There was one and one only journalist, Western journalist, still left in East Timor, and that was you. You did have a way of communicating with the outside world: I recall hearing you in an interview on Radio New Zealand with Kim Hill. You were in the mountains talking in a low voice so as not to be heard by the Indonesian military, presumably. It felt so authentic - the roosters were crowing in the background, it was really spine-chilling stuff. I know obviously you can't say that about yourself, but you undertook an amazing role that deserves credit here.

Max Stahl: Well, thank you. The most important thing here is the story itself and the shared role that I played in it is a privilege. But it's a role which was important as part of the nation-building process and that's all I was interested in saying here. Recently I had cancer in 2012, and I was in the UK being treated, and then President, José Ramos Horta, went on TV-I didn't know about this, of course, it was in Timor-he went on TV and said, 'This is Max Stahl, this is what's happening and please pray'. And the result was extraordinary, I don't know if it was just an intervention, but they had made a kind of a totem out of me. I became a way for people to remember and to share the story, as I was part of the story, as Horta said.

But there are many ways in which the government is trying to create the story of a 
nation, to put Nelson on his column, in the consciousness of the people. I wore this tshirt today, which is one of a number that were made in Timor. People who are veterans of the Dili massacre of Santa Cruz wear them especially on November 12 every year, when thousands of people walk the road that leads to the Santa Cruz cemetery massacre. Even in the middle of the crisis of 2006, warring factions of young people who had been fighting each other, came together on that anniversary talking about how they shared the sacrifice of that day.

When I was filming the crisis - there are some images that were fairly hairy-I was in the middle of people firing rocks and even bullets at each other. But both sides were keen to see me, so I wore this hat or a hat like it, it's like a brand. Both of them thought that they were were the ones pursuing the tradition of the struggle for independence, nobody was against it, everybody was for it, but they didn't agree how to continue this struggle. However, I was able to enter their situation, filming people being shot, people throwing rocks. So the earlier story that I was involved with had the potential to bring people together even in the midst of that division, that terrible crisis which threatened civil war at a certain point.

Audience speaker: What do you think of the way the story's being told through that very expensive national museum?

Max Stahl: The National Museum, of course, is a part of the National Resistance Museum, and indeed we have been asked by the government to work with them, and they are actually building us a building behind it now as part of the bigger complex. There are various issues to sort out, but I think the museum is beautiful. At a certain level it's going to appeal to people and convey and communicate something important.

The museum will provide one way that memory can be valued and celebrated. My addition is that it shouldn't be the main, or only way to do so. It could provide a base that we should try to open up to reach as many people as possible; not just wait for them to come to the museum, because of course the vast majority of Timor-Leste will never go to the museum. They feel intimidated by such a place even if they could go there.

By engaging in a debate, in a process of communicating with different communities, perception and understanding changes all the time. We have many other concerns and interests apart from the struggle, but memory is of course a key and a core issue for us. We continue to work as people looking for the remains of the dead, which are scattered all over Timor. There are ceremonies, both traditional and Catholic, which surround that process of reclamation. They are part of a memory which is symbolic, like a museum.

How many people actually go to museums? Probably a tiny number in any country. But I bet you the vast majority of them would be very offended if they didn't have a museum. They want there to be a museum, a museum is part of showing that we have a history, that we have a story. Even if you never go there in your entire life, you definitely

130 PACIFIC JOURNALISM REVIEW 21(1) 2015 
want it there. So it's important that it exists and it should look good: it becomes a monument in itself. That process works. I talk at the museum a fair bit and work there, but most of what we do is not there but in the communities or on the editing table.

We work with the French a lot, because their National Archive, which has supported us from 2005, proposed us for registration by UNESCO in a non-physical main programme called A Memory of the World. So we are a kind of the Ayres Rock, if you like, of East Timor. A non-physical one. I don't know if many people are going to look at the 450 hours of footage we have in the French National Archive even if they could. But the fact that it's there is important not just to Timor, it's also important to people around the world. The contribution that people made in New Zealand and Australia, around the world, is part of that story. It is one of the reasons why they registered it, because the story that they were registering was something on the cusp of change, changing the relationship between news and the public.

Timor-Leste is the first country to construct its national story through audio-visual means. A small number of people that I met in the mountains manage to make their voice heard by building museums, kilometres from the nearest road. There is a museum right now, built in the mountains in 1991 for the communities there who rarely watch TV — at least not that sort of TV.

The circle of silence that was surrounding them begins to break - and what was that circle? Silence had stopped them in communicating with people like yourselves, allies outside their country who shared their values. Through producing a shared statement and demonstrating their values, small groups of people around the globe were able to create a movement which was eventually able to overturn the diplomatic 'strategic interest' based alliances which had consigned East Timor to the disposable bin. And by humanising that bin, over a process of time with a cooperation of people, engaged people all over the place, the story changed. And when the story changed, the reality of politics and the cynical declarations of people (like the Australian ambassador) who talked about the suffering of East Timor being a sad reality, was exposed as not only immoral but also lacking in the basic values which most Australians wish to claim. Also not a good move professionally because he lost power!

And that, to me, is the story that is unique about Timor. It is much bigger than the country itself. It shows an ability for a group of people in an extreme situation to communicate through their humanity to people around the world and, through that, to transform the struggle. Timor didn't just keep on struggling until the end. It won by communication, by extremely skilful use of their story.

\section{Note}

1. Kirsty Sword Gusmão is an Australian-Timor-Leste activist who served as the First Lady of East Timor from 2002 until 2007. She is married to Xanana Gusmão, a resistance leader against the Indonesians, ex-Prime Minister and former President of Timor Leste. She worked with Peter 


\section{DOCUMENTARY PRACTICE IN THE ASIA-PACIFIC}

Gordon and Max Stahl on the 2012 documentary Bloodshot: The Dreams and Nightmares of East Timor (www.bloodshot-documentary-east-timor.com).

The video version of this address, 'Without an identity, you don 't have democracy', can be viewed on the Pacific Media Centre channel at: www.youtube.com/watch? $v=L x o 0 s v o Q d H g$

Pacific Journalism Review editors thank Hayley Becht, a Bachelor of Communication Studies final year Television and Screen Production student at Auckland University of Technology, for transcribing this address.

\section{AUT COMMUNICATION STUDIES, TELEVISION \& SCREEN PRODUCTION}

\section{AOTT}

A focus on real people to tell their stories

The ability to make exciting and innovative documentaries and screen productions that tell a good story is at the heart of undergraduate and postgraduate study at AUT

The papers cover producing, directing, script writing, camera and sound recording, editing, production management and interviewing. They are taught by passionate, award-winning practitioners.

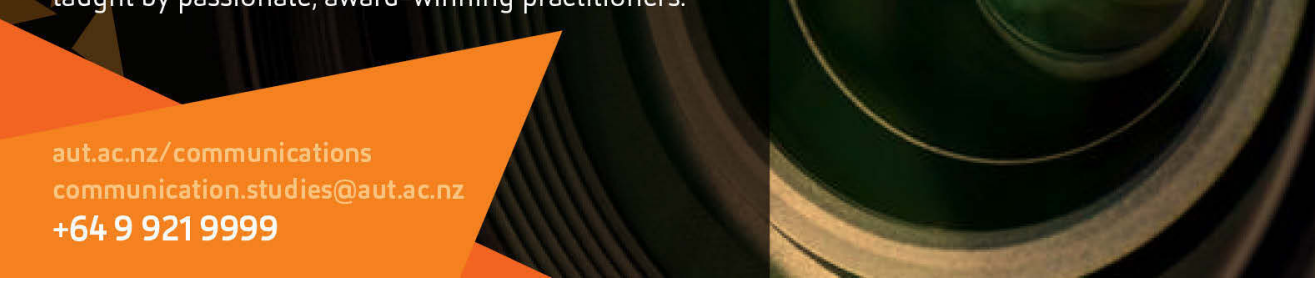

132 PACIFIC JOURNALISM REVIEW 21(1) 2015 